\title{
More rapid restoration of pituitary content of follicle- stimulating hormone than of luteinizing hormone after depletion by oestradiol-17 $\beta$ in ewes
}

\author{
G. B. Di Gregorio, J. P. Kile, R. H. Herring and T. M. Nett \\ Animal Reproduction and Biotechnology Laboratory, Department of Physiology, Colorado State \\ University, Fort Collins, CO 80523, USA
}

\begin{abstract}
Summary. To test the hypothesis that the synthesis and secretion of follicle-stimulating hormone (FSH) and luteinizing hormone $(\mathrm{LH})$ are differentially regulated after depletion by oestradiol, circulating concentrations of oestradiol were maintained at $\sim 30 \mathrm{pg} / \mathrm{ml}$ for 16 days in each of 35 ovariectomized ewes. Five other ovariectomized ewes that did not receive oestradiol implants served as controls. After treatment with oestradiol, implants were removed and pituitary glands were collected from each of 5 ewes at $0,2,4,8,12,16$ and 32 days thereafter and amounts of mRNA for gonadotrophin subunits and contents of $\mathrm{LH}$ and FSH were quantified. Before collection of pituitary glands, blood samples were collected at 10 -min intervals for $6 \mathrm{~h}$. Treatment with oestradiol reduced $(P<0.05)$ steady-state concentrations of LH $\beta$ - and FSH $\beta$ subunit $m$ RNAs and pituitary and serum concentrations of these hormones. At the end of treatment the amount of mRNA for $\mathrm{FSH} \beta$-subunit was reduced by $52 \%$ whereas that for LH $\beta$-subunit was reduced by $93 \%$. Steady-state concentrations of mRNA for FSH $\beta$-subunit returned to control values within 2 days of removal of oestradiol, but 8 days were required for concentrations of FSH in the pituitary and serum to return to control values. Steady-state concentrations of mRNA for LH $\beta$-subunit and mean serum concentrations of LH returned to control values by Day 8, but pituitary content of LH may require as long as 32 days to return to control levels. Therefore, replenishment of FSH $\beta$-subunit mRNA preceded increases in pituitary and serum concentrations of FSH. Less time was needed to restore pituitary content of FSH than of LH.
\end{abstract}

Keywords: oestradiol; gonadotrophins; messenger RNA; sheep

\section{Introduction}

Prolonged increases in circulating concentrations of oestradiol and progesterone, during late gestation are believed to be responsible for the decrease in circulating concentrations of luteinizing hormone (LH) observed at this time (Stabenfeldt et al., 1972; Carnegie \& Robertson, 1978). The decrease in serum concentrations of LH appears to be related to a reduction in pituitary content of this hormone (Moss et al., 1981). Although progesterone acts on the hypothalamus to reduce the pulsatile release of gonadotrophin-releasing hormone (GnRH) (Karsch et al., 1987), it reportedly has little effect on the anterior pituitary gland and the synthesis of LH (Clarke \& Cummins, 1984; Hamernik et al., 1987). Oestradiol also acts at the hypothalamus to obliterate GnRH release (Karsch et al., 1987). Moreover, high concentrations of oestradiol can act directly at the anterior pituitary gland (Nett et al., 1990a) to reduce the amount of messenger RNA (mRNA) for $\alpha$ - and LH $\beta$-subunits (Nilson et al., 1983; Wise et al., 1985) and the $\beta$-subunit of follicle-stimulating 
hormone (FSH; Nett et al., 1990b). Therefore, it appears that oestradiol is the steroid primarily responsible for reducing synthesis of gonadotrophins (Moss et al., 1981; Tamanini et al., 1986).

In addition to decreasing the synthesis of FSH and $\mathrm{LH}$, treatment with oestradiol also decreases circulating concentrations of these gonadotrophins (Moss et al., 1981). However, during the postpartum period, i.e. after a decline in circulating concentrations of oestradiol, circulating concentrations of FSH return to normal more rapidly than circulating concentrations of LH (Moss et al., 1985; Nett et al., 1988). From these data it can be inferred that oestradiol inhibits the synthesis of both $\mathrm{LH}$ and FSH, but synthesis and secretion of FSH recover more rapidly from inhibition by oestradiol than does LH. From this information, we hypothesize that there is differential regulation of the synthesis and secretion of FSH and LH, even in the absence of ovarian hormones. This study examined the time required for the pituitary gland to replenish stores of FSH and LH after their depletion by chronic treatment with oestradiol.

\section{Materials and Methods}

Experimental design. Forty mature Columbia-Corriedale ewes weighing $\sim 45 \mathrm{~kg}$ were randomly assigned to 8 groups ( 5 ewes/group) in December. Animals were ovariectomized at least 8 weeks before the experiment. Thirty-five of the ewes received 6 subcutaneous silastic implants containing oestradiol (Karsch et al., 1980) to increase circulating concentrations to $\sim 30 \mathrm{pg} / \mathrm{ml}$ (Crowder et al., 1982). Five ovariectomized ewes did not receive implants and served as controls. After treatment with oestradiol for 16 days, implants were removed (designated Day 0 ) and pituitary glands were collected from each of 5 ewes $0,2,4,8,12,16$ and 32 days later. Connective tissue and the posterior pituitary gland were removed. The anterior pituitary gland was divided midsagittally and stored at $-70^{\circ} \mathrm{C}$. Prior to collection of pituitary glands, blood samples were collected from each animal at 10-min intervals for $6 \mathrm{~h}$ for analysis of LH and FSH.

Preparation of total RNA from pituitary glands. Half of the pituitary gland was used to quantify amounts of mRNA for LH $\beta$ - and FSH $\beta$-subunits, and growth hormone (GH). Total RNA was extracted using lithium chloride, as described by Auffray \& Rougeon (1980), but with minor modifications. Half of each pituitary gland was homogenized in $10 \mathrm{ml}$ of $6 \mathrm{M}$ urea and $3 \mathrm{M}$ lithium chloride buffer (buffer $\mathrm{A}$ ) using a polytron (setting $8,1 \mathrm{~min}$; Brinkman Instruments, Westbury, NY, USA) and left overnight at $4^{\circ} \mathrm{C}$. The following day the homogenate was centrifuged at $17000 \mathrm{~g}$ for $30 \mathrm{~min}$ and washed with $6 \mathrm{ml}$ buffer A. The supernatant was discarded and $6 \mathrm{ml}$ of $10 \mathrm{~mm}$ Tris buffer containing $1 \mathrm{~mm}$ EDTA, $0.5 \%$ sodium dodecyl sulphate (SDS) and proteinase $\mathrm{K}(100 \mu \mathrm{g} / \mathrm{ml})$ were added. The solution was incubated for $30 \mathrm{~min}$ at $37^{\circ} \mathrm{C}$ and then extracted sequentially with equal volumes of phenol, then phenol:chloroform (1:1) and finally chloroform. Sodium acetate (final concentration $0.3 \mathrm{M})$ and absolute ethanol $\left(-20^{\circ} \mathrm{C}, 75 \%\right.$ final concentration) were added to the extract and incubated overnight at $-20^{\circ} \mathrm{C}$. The precipitate was pelleted $(17000 \mathrm{~g}$ for $20 \mathrm{~min}$ ) and washed with $600 \mu \mathrm{l} 75 \%$ ethanol. The pellet was resuspended in $1 \mathrm{ml}$ diethylpyrocarbonate-treated water and frozen at $-70^{\circ} \mathrm{C}$ prior to analysis.

Purity and amount of RNA were determined using a Beckman DU-64 spectrophotometer (Beckman Instruments Inc., Fullerton, CA, USA). A random sample of $2 \mu \mathrm{g}$ RNA was electrophoresed through a $0.8 \%$ nondenaturing agarose gel (Maniatis et al., 1989) and stained with ethidium bromide to ensure that there was no detectable contamination with DNA or degradation of RNA.

Quantification of gonadotrophin subunit mRNAs. Quantification of mRNAs for LH $\beta$ - and FSH $\beta$-subunits and GH was by direct transfer of $25 \mu \mathrm{g}$ total RNA for each sample in triplicate to a nylon filter (Gene Screen, NEN Research Products, Boston, MA, USA) using a slot blot apparatus (Kafatos et al., 1979; Nett et al., 1990a). Transcripts of RNA specific for LH $\beta$ - and FSH $\beta$-subunits were generated from cDNA clones containing the sequences for FSH $\beta$ - and (Maurer \& Beck, 1986) and LH $\beta$-subunits (Maurer, 1987) as described by Melton et al. (1984) and these standards were transferred to each filter in amounts ranging from 25 to $1250 \mathrm{pg}$. Samples and standards on filters were hybridized with ${ }^{32}$ P-labelled RNA probes $\left(\sim 10^{7}\right.$ total c.p.m. for each probe) specific for LH $\beta$ - (Virgin et al., 1985) and FSH $\beta$-subunits (Maurer \& Beck, 1986) or a ${ }^{32} \mathrm{P}$-labelled cDNA specific for GH (Nilson et al., 1983) in $50 \%$ formamide overnight at $45^{\circ} \mathrm{C}$ and then washed with $2 \times \mathrm{SSC}$ containing $0.1 \%$ SDS at $98^{\circ} \mathrm{C}$ for $30 \mathrm{~min}$ followed by washing with $0.1 \times$ SSC containing $0.1 \%$ SDS at $98^{\circ} \mathrm{C}$ for $30 \mathrm{~min}$. The SSC $(1 \times)$ wash buffer contained $150 \mathrm{~mm}-\mathrm{NaCl}$ and $15 \mathrm{~mm}$ sodium citrate, $\mathrm{pH} 7.0$ (Maniatis et al., 1989). After hybridization and washing, the nylon filters were placed with X-ray film (Kodak XAR-5, Eastman Kodak Co., Rochester, NY, USA) for $12 \mathrm{~h}$ at $-70^{\circ} \mathrm{C}$. Autoradiographs were scanned using a GS 300 Transmittance/Reflectance Scanning Densitometer (Hoefer Scientific Instruments, San Francisco, CA, USA). An average area for each sample (based on 3 replicates) was calculated and the concentration (pg mRNA/ $\mu \mathrm{g}$ total RNA) for the gonadotrophin subunits was calculated from the standard curve.

Quantification of mRNA for GH was used as an alternative to probing nylon filters with oligo-dT to demonstrate that the same amount of RNA was loaded onto each slot and also to demonstrate that treatment with oestradiol specifically influenced mRNAs for gonadotrophins rather than having induced a general suppression of pituitary hormone synthesis. Transcripts of $\mathrm{mRNA}$ for GH for use as standards were unavailable and therefore the amount of 
mRNA for GH was determined using random oligonucleotide-labelled, single-stranded cDNA probes and expressed in arbitrary units (Woychik et al., 1982).

Pituitary and circulating concentrations of $\mathbf{L H}$ and FSH. Half of each pituitary gland was homogenized in $0.01 \mathrm{M}$ phosphate buffer containing $0 \cdot 14 \mathrm{M}$ saline solution and $0 \cdot 1 \%$ gelatin $(\mathrm{pH} 7.0)$ with a polytron (dial set at $8,1 \mathrm{~min}$ ). Concentrations of LH (Niswender et al., 1969) and FSH (L'Hermite et al., 1972) in supernatants and serum samples were quantified by radioimmunoassay. Reference standards were NIH-LH-S24 (2.3 $\times$ NIH-LH-S1) and NIH-FSHS12 $(1.25 \times$ NIH-FSH-SI). Sensitivity of the assay was $0.11 \mathrm{ng} / \mathrm{ml}$ for LH and $2.8 \mathrm{ng} / \mathrm{ml}$ for FSH. The interassay and intra-assay coefficients of variation were 11.2 and $3.9 \%$, respectively, for the LH assay, and 15.7 and $9.7 \%$, respectively, for the FSH assay.

Statistical analysis. Data were log-transformed and a one-way analysis of variance (ANOVA; Steel \& Torrie, 1980) was used to identify treatment effects. Significant differences between treatments were identified using Duncan's New Multiple Range Test (Steel \& Torrie, 1980). The computer program called sUMmIT, which uses the criteria proposed by Goodman \& Karsch (1980) to identify a pulse of LH, was used for analysis of LH pulses in serum. A confidence limit for each sample was calculated according to the method of Duddelson et al. (1972). Differences in frequency of LH pulses among treatment groups were evaluated using the Wilcoxon test (Steel \& Torrie, 1980). Mean serum concentrations of LH and FSH were determined by averaging the hormone concentration for all blood samples taken over the 6-h period for each animal. Differences in mean and baseline serum concentrations of gonadotrophins among treatments were determined using a one-way ANOVA.

\section{Results}

Chronic treatment with oestradiol reduced steady-state concentrations of mRNA for FSH $\beta$ - and LH $\beta$-subunits, and pituitary and serum concentrations of these hormones. The amount of mRNA for FSH $\beta$-subunit was only $48 \%(P<0.05)$ of that in control ewes after 16 days of oestradiol treatment (Fig. 1), but it increased to control levels $(P>0.05)$ within 2 days after removal of oestradiol and remained stable until Day 32, except for a transient decrease $(P<0.05)$ on Day 12. Treatment with oestradiol also reduced $(P<0.05)$ pituitary content and mean serum concentrations of FSH, but both returned to control levels by Day 8 and remained stable until Day 32 .

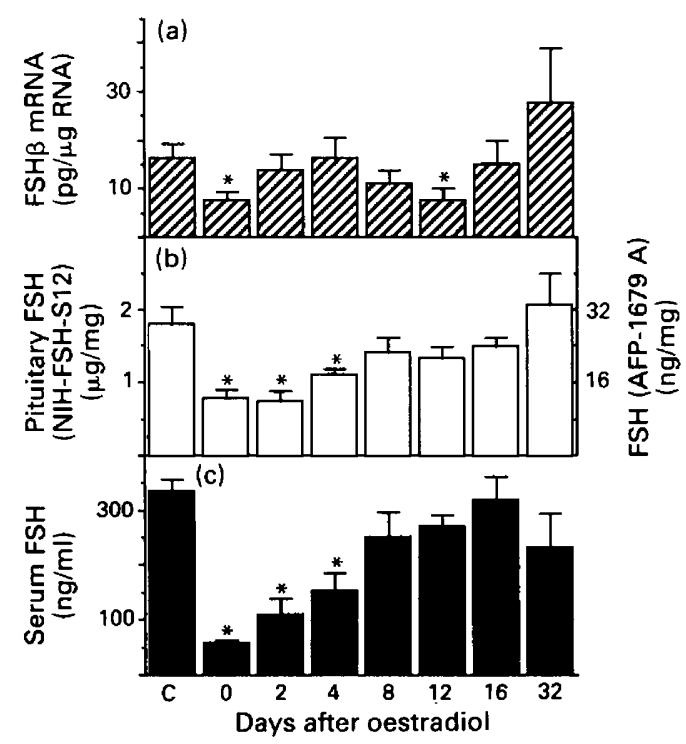

Fig. 1. (a) Amount of mRNA for (b) $\beta$ subunit of follicle-stimulating hormone (FSH) in pituitaries and (c) serum concentrations of FSH at different times after removal of oestradiol. Ovariectomized control $(C)$ ewes did not receive steroid implants. Values are means \pm s.e.m. $\left(n=5\right.$ ewes/group); ${ }^{*}$ means are different $(P<0.05)$. 


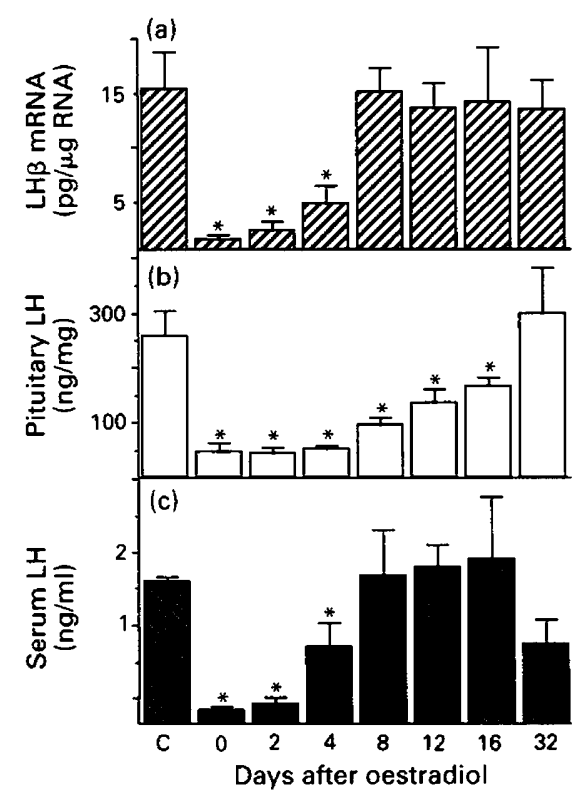

Fig. 2. (a) Amount of mRNA for (b) $\beta$ subunit of luteinizing hormone ( $\mathrm{LH}$ ) in pituitaries and (c) pituitary and serum concentrations of $\mathbf{L H}$ at different times after removal of oestradiol. Ovariectomized control $(C)$ ewes did not receive steroid implants. Values are means \pm s.e.m. $(n=5$ ewes/group $) ;{ }^{*}$ means are different $(P<0 \cdot 05)$.

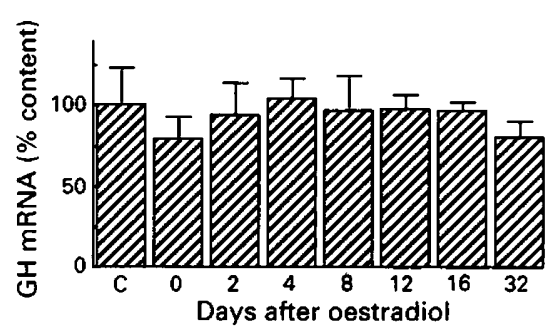

Fig. 3. Content of mRNA for gonadotrophins $(\mathrm{GH})$ expressed as percentage of ovariectomized control (C) ewes in pituitaries at different times after removal of oestradiol.

The reason for the decrease in mRNA for FSH $\beta$-subunit on Day 12 is not known, but was apparently of little physiological importance, because it was not accompanied by a decrease in pituitary or serum concentrations of FSH.

Treatment with oestradiol also reduced $(P<0.05)$ the amount of mRNA for LH $\beta$-subunit to $7 \%$ of that in control ewes (Fig. 2). However, 8 days were required for steady-state concentrations of mRNA for LH $\beta$-subunit to return to control levels (compared with 2 days for mRNA for FSH $\beta$-subunit) and thereafter they remained unchanged until Day 32. Pituitary content of LH was reduced to $18 \%$ of that of the controls $(P<0.05)$ as a result of treatment; 8 days after removal of oestradiol, it had increased $(P<0.05)$ compared with Day 0 , and it returned to values observed in controls by Day 32. Treatment with oestradiol also reduced $(P<0.05)$ mean serum concentrations of $\mathrm{LH}$, but $\mathrm{LH}$ had begun to increase by Day 4 and was similar to controls by Day $8(P>0.05)$ and remained at this level until Day 32.

There was no change $(P>0.5)$ in amounts of mRNA for gonadotrophins throughout the experimental period (Fig. 3). 
Table 1. Pulse frequency and amplitude, and basal concentrations of luteinizing hormone in serum at different times after treatment of ewes with oestradiol. Values are expressed as mean \pm s.e.m. ( $n=5$ ewes/group); ovariectomized ewes did not receive implants and served as controls

\begin{tabular}{|c|c|c|c|}
\hline $\begin{array}{l}\text { Treatment } \\
\text { (Day) }\end{array}$ & $\begin{array}{c}\text { No. pulses } \\
(/ \mathrm{h})\end{array}$ & $\begin{array}{l}\text { Pulse amplitude } \\
\text { (ng) }\end{array}$ & $\begin{array}{l}\text { Baseline concentration } \\
\qquad(\mathrm{ng} / \mathrm{ml})\end{array}$ \\
\hline Control & $1 \cdot 2 \pm 0 \cdot 1$ & $1 \cdot 3 \pm 0 \cdot 2$ & $1.0 \pm 0.2$ \\
\hline 0 & $0^{*}$ & $0^{*}$ & $0 \cdot 1 \pm 0.1^{*}$ \\
\hline 2 & $0 \cdot 6 \pm 0 \cdot 1^{*}$ & $0.3 \pm 0.1^{*}$ & $0.1 \pm 0.2^{*}$ \\
\hline 4 & $1.2 \pm 0.3$ & $1.4 \pm 0.5$ & $0.6 \pm 0.3$ \\
\hline 8 & $1.3 \pm 0.1$ & $1.7 \pm 0.4$ & $1.9 \pm 0.9$ \\
\hline 12 & $1.4 \pm 0.1$ & $1.7 \pm 0.3$ & $1 \cdot 3 \pm 0.5$ \\
\hline 16 & $1.2 \pm 0.2$ & $1 \cdot 7 \pm 0.8$ & $1.5 \pm 0.6$ \\
\hline 32 & $0.7 \pm 0.3$ & $0.7 \pm 0.1$ & $0.7 \pm 0.3$ \\
\hline
\end{tabular}

*Different from controls, $P<0.05$.

The average number of $\mathrm{LH}$ pulses in serum and pulse amplitude were reduced $(P<0.05)$ following treatment with oestradiol, returned to control levels by Day 4 , and remained constant for the duration of the experiment (Table 1).

\section{Discussion}

The present study is the first to compare changes in amounts of mRNAs for gonadotrophin subunits with changes in pituitary and serum concentrations of these hormones following removal of chronically administered oestradiol in ewes. Chronic treatment with oestradiol dramatically reduced pituitary concentrations of gonadotrophins, presumably by reducing amounts of mRNA for $L H \beta$ and FSH $\beta$ subunits. These results are in agreement with those of Shupnik et al. (1988), who demonstrated that chronic treatment with oestradiol dramatically suppressed transcription of the gene for the LH $\beta$ subunit in rat pituitary glands in vivo. A direct negative effect of oestradiol on transcription of the ovine FSH $\beta$-subunit gene in vitro has been reported (Phillips et al., 1988). Oestradiol, like other steroid hormones, regulates gene transcription by binding to a nuclear receptor protein to form a steroid-receptor complex that interacts with DNA at a specific oestrogen response-element (Jost et al., 1984; Klein-Hitpass et al., 1986; Maurer \& Notides, 1987). There is an oestrogen response-element on the rat LH $\beta$-subunit gene (Shupnik et al., 1989) and a similar sequence has been tentatively identified on the bovine FSH $\beta$-subunit gene (Kim et al., 1988). Thus, there is compelling evidence for an oestrogen response-element on the ovine gonadotrophin $\beta$ subunit genes; the data of Shupnik et al. (1988) and of Nett et al. (1990a) suggest that oestradiol has a direct effect at the anterior pituitary gland in reducing steady-state concentrations of mRNA for LH $\beta$ and FSH $\beta$ subunits, as well as affecting the secretion of GnRH from the hypothalamus (Karsch et al., 1987).

Increases in the amount of mRNAs for gonadotrophin subunits preceded increases in pituitary concentrations of gonadotrophins after removal of oestradiol. The interval between replenishing mRNA for the FSH $\beta$ subunit and restoring pituitary concentrations of FSH was $\sim 6$ days, whereas complete restoration of pituitary concentrations of LH may require as long as 24 days after replenishment of mRNA for the LH $\beta$ subunit. In ewes in early post partum, a state in which gonadotrophs are also recovering from the prolonged suppression by steroid hormones, replenishment of mRNA for the subunits of LH also precedes replenishment of pituitary content of LH by several days (Wise et al., 1985). In a separate study, Wise et al. (1986) observed an increase in the percentage of cells in the anterior pituitary that could be identified as gonadotrophs in immuno- 
cytochemistry as well as an increase in the percentage of gonadotroph volume occupied by secretory granules with time after parturition. Thus, it seems clear that gonadotrophs synthesize a number of proteins other than LH as they recover from steroid-induced inhibition. We speculate that during this recovery period the gonadotroph must secrete nearly all the LH it can synthesize to maintain normal serum concentrations. Therefore, although gonadotrophs were apparently synthesizing enough $\mathrm{LH}$ to restore serum concentrations, the rate of synthesis of $\mathrm{LH}$ apparently was not sufficient to also replenish cellular content of $\mathrm{LH}$.

Replenishment of mRNA and pituitary stores of FSH occurred earlier than replenishment of mRNA and pituitary stores of $\mathrm{LH}$ following removal of oestradiol. To determine why this differential rate of replenishment might occur, we calculated the quantities of LH and FSH that were needed to replenish content in the pituitary gland. To make this calculation it was necessary to have highly purified standard preparations of $\mathrm{LH}$ and FSH. For LH we used NIH-LH-S24 $(2 \cdot 3 \times \mathrm{NIH}-$ LH-SI) and for FSH we used an affinity-purified standard preparation obtained from Dr A. F. Parlow (AFP-1679A, $60 \times$ NIH-FSH-S1). Assuming the affinity-purified standard preparation of FSH (AFP-1679A) was pure, we estimated that the pituitary gland needs to synthesize $0.52 \mathrm{nmol}$ of FSH to restore pituitary content of FSH. Likewise, assuming that the NIH-LH-S24 standard was pure, the pituitary gland must produce $6.4 \mathrm{nmol}$ of $\mathrm{LH}$ to restore pituitary content to the level measured in ovariectomized controls. In ewes not treated with oestradiol, the amount of mRNA for the FSH $\beta$ subunit was approximately the same as that for the LH $\beta$ subunit; but after treatment with oestradiol the amount of mRNA for FSH $\beta$ subunit was reduced by only $52 \%$ whereas the amount of mRNA for the LH $\beta$ subunit was reduced by $93 \%$. The half-life for mRNA for ovine LH $\beta$ and FSH $\beta$ subunits has not been measured. If one were to assume that both mRNAs have similar rates of transcription and stability among the heterogeneous population of gonadotrophs (for review, see Childs, 1986), mRNA for FSH $\beta$ subunit would be expected to return to normal more rapidly when the inhibition by oestradiol is removed. Therefore, the more rapid replenishment of pituitary concentrations of FSH may have been due to (i) a smaller reduction in the amount of mRNA for FSH $\beta$ subunit in response to chronic treatment with oestradiol and (ii) the fewer FSH molecules relative to $\mathrm{LH}$ that had to be synthesized to restore pituitary concentrations.

A variety of hormones is involved in regulating gonadotrophin synthesis and secretion. Reports involving either hypothalamic -pituitary-disconnected, ovariectomized ewes (Hamernik et al., 1986; Hamernik \& Nett, 1988) or ewes actively immunized against GnRH (McNeilly et al., 1986) suggest that GnRH is important for maintaining pituitary content of both FSH and LH. In addition, progesterone reduces the secretion, but not the synthesis, of LH (Hamernik et al., 1987) presumably by acting at the hypothalamus to modify the release of GnRH (Goodman \& Karsch, 1980; Karsch et al., 1987). Therefore, it is possible that, in the present study, restoration of pituitary content of LH took longer than that of FSH because LH was being released nearly as rapidly as it was being synthesized. This hypothesis is supported by data in the present study which show that LH pulses in serum occurred at $1.2 \pm 0.3$ pulses/h within 4 days of removal of oestradiol, which was similar to the frequency at which pulses occurred in control ewes. In addition to synthesizing $6.4 \mathrm{nmol}$ to replenish stores of $\mathrm{LH}$, the pituitary gland must also synthesize enough $\mathrm{LH}$ to restore and maintain serum concentrations of $\mathrm{LH}$ at control levels. We calculated from its metabolic clearance rate (Akbar et al., 1974), that $\mathrm{LH}$ is released from the pituitary gland at $2.6 \mathrm{pmol} / \mathrm{min}$ (3.7 nmol/day). Thus, restoration of serum concentrations of $\mathrm{LH}$ appears to occur at the expense of restoring pituitary content of this hormone. If ewes in this study had been treated with progesterone after removal of oestradiol to suppress release, but not synthesis, of LH, pituitary content of LH might have been restored more rapidly (Tamanini et al., 1988).

We conclude from the data obtained in this study that, after pituitary content of gonadotrophins has been reduced, less time is required to restore pituitary concentrations of FSH than is needed for that of LH. This conclusion is based on the following: (i) less time is needed to restore amounts of mRNA for the FSH $\beta$ subunit than for the LH $\beta$ subunit and (ii) the interval between 
replenishing the FSH $\beta$ subunit $\mathrm{mRNA}$ and restoring concentrations of FSH is $\sim 6$ days, whereas the interval between replenishing LH $\beta$ subunit mRNA and restoring concentrations of LH may be as long as 24 days. This appears to occur because there is much less FSH than LH in the anterior pituitary gland of ewes and a large proportion of the LH must be secreted to maintain serum concentrations because of its short half-life.

\section{References}

Akbar, A.M., Nett, T.M. \& Niswender, G.D. (1974) Metabolic clearance and secretion rates of gonadotropins at different stages of the estrus cycle in ewes. Endocrinology 94, 1318-1324.

Auffray, C. \& Rougeon, F. (1980) Purification of mouse immunoglobulin heavy-chain messenger RNAs from total myeloma tumor RNA. Eur. J. Biochem. 107, 303-314.

Carnegie, J.A. \& Robertson, H.A. (1978) Conjugated and unconjugated estrogens in fetal and maternal fluids of the pregnant ewe: a possible role for estrone sulfate during pregnancy. Biol. Reprod. 19, 202-211.

Childs, G.V. (1986) Functional ultrastructure of gonadotrophs: a review. Current Topics in Neuroendocr. 7, 49-97.

Clarke, I.J. \& Cummins, J.T. (1984) Direct pituitary effects of estrogen and progesterone on gonadotropin secretion in the ovariectomized ewe. Neuroendocrino$\log y 39,267-274$.

Crowder, M.E., Gilles, P.A., Tamanini, C., Moss, G.E. \& Nett, T.M. (1982) Pituitary content of gonadotropins and GnRH-receptors in pregnant, post-partum and steroid-treated ovx ewes. J. Anim. Sci. 54, 1235-1242.

Duddelson, W.G., Midgley, Jr A.R. \& Niswender G.D. (1972) Computer program sequence for analysis and summary of radioimmunoassay data. Comp. Biomed. Res. 5, 205.

Goodman, R. L. \& Karsch, F.J. (1980) Pulsatile secretion of luteinizing hormone: differential suppression by ovarian steroids. Endocrinology 107, 1286-1290.

Hamernik, D.L., Kim, K.E., Maurer, R.A. \& Nett, T.M. (1987) Progesterone does not affect the amount of mRNA for gonadotropins in the anterior pituitary gland of ovariectomized ewes. Biol. Reprod. 37, 1225-1232.

Hamernik, D.L., Crowder, M.E., Nilson, J.H. \& Nett, T.M. (1986) Measurement of mRNA for luteinizing hormone $\beta$-subunit, $\alpha$-subunit, growth hormone and prolactin following hypothalamic-pituitary disconnection in the ewe. Endocrinology 119, 2704-2710.

Hamernik, D.L. \& Nett, T.M. (1988) Gonadotropinreleasing hormone increases the amount of messenger ribonucleic acid for gonadotropins in ovariectomized ewes after hypothalamic-pituitary disconnection. Endocrinology 122, 959-966.

Jost, J.P., Seldran, M. \& Geiser, M. (1984) Preferential binding of estrogen receptor complex to a region containing the estrogen-dependent hypomethylation site preceding the chicken vitellogenin II gene. Proc. Natl Acad. Sci., USA 81, 429-433.

Kafatos, F., Jones, C.W. \& Efstratiadis, A. (1979) Determination of nucleic acid sequence homologies and relative concentrations by a dot hybridization procedure. Nucleic Acids Res. 7, 1541-1553.
Karsch, F.J., Legan, S.J., Ryan, K.D. \& Foster, D.L. (1980) Importance of oestradiol and progesterone in regulating $\mathrm{LH}$ secretion and estrous behavior during the sheep estrous cycle. Biol. Reprod. 233, 404-409.

Karsch, F.J., Cummins, J.T., Thomas, G.B. \& Clarke, I.J. (1987) Steroid feedback inhibition of pulsatile secretion of gonadotropin-releasing hormone in the ewe. Biol. Reprod. 36, 1207-1218.

Kim, K.E., Gordon, D.F. \& Maurer, R.A. (1988) Nucleotide sequence of the bovine gene for folliclestimulating hormone $\beta$-subunit. DNA 7, 227-233.

Klein-Hitpass, L., Schorpp, M., Wagner, U. \& Ryffel, G.U. (1986) An estrogen-responsive element derived from the $5^{\prime}$ flanking region of the Xenopus vitellogenin A2 gene functions in transfected human cells. Cell 46, 1053-1061.

L'Hermite, M., Niswender, G.D., Reichert Jr., L.E. \& Midgley Jr., A.R. (1972) Serum follicle-stimulating hormone in sheep as measured by radioimmunoassay. Biol. Reprod. 6, 325-332.

Maniatus, T., Fritsch, E.F. \& Sambrook, J. (1989) Molecular Cloning, A Laboratory Manual, 2nd edn, pp. 6.4-6.5. Eds C. Nolan, N. Ford, M. Ferguson \& M. Ockler. Cold Spring Harbor Press, New York.

Maurer, R.A. (1987) Sequence of cloned bovine LH- $\beta$ cDNA. J. Biol. Chem. 260, 4684.

Maurer, R.A. \& Beck, A. (1986) Isolation and nucleotide sequence analysis of a cloned cDNA encoding the $\beta$ subunit of bovine follicle-stimulating hormone. DNA $5,363-369$.

Maurer, R. A. \& Notides, A.C. (1987) Identification of an estrogen-responsive element from the 5 -flanking region of the rat prolactin gene. Mol. Cell. Biol. 7, 4247-4254.

McNeilly, A.S., Jonassen, J.A. \& Fraser, H. (1986) Suppression of follicular development after chronic LHRH immunoneutralization in the ewe. J. Reprod. Fert. 76, 481-490.

Melton, D.A., Krieg, P.A., Rebagliati, M.R., Maniatis, T., Zinn, K. \& Green, M.R. (1984) Efficient in vitro synthesis of biologically active RNA and RNA hybridization probes from plasmids containing a bacteriophage SP6 promoter. Nucleic Acids Res. 12, 7033-7035.

Moss, G.E., Crowder, M.E. \& Nett, T.M. (1985) GnRHreceptor interaction. IV. Effect of progesterone and oestradiol on hypophyseal receptors for GnRH, and serum and hypophyseal concentrations of gonadotropins in ovariectomized ewes. Biol. Reprod. 25, 938-944.

Moss, G.E., Crowder, M.E. \& Nett, T.M. (1981) Pituitary concentrations of gonadotropins and receptors for GnRH in suckled beef cows at various intervals after calving. J. Anim. Sci. 60, 285-293.

Nett, T.M., Cermak, D., Braden, T., Manns, J. \& Niswender, G.D. (1988) Pituitary receptors for 
GnRH and oestradiol, and pituitary content of gonadotropins in beef cows. Il. Changes during the postpartum period. Dom. Anim. Endocr. 5, 81-89.

Nett, T.M., Flores, J.A., Carnevali, F. \& Kile, J.P. (1990a) Evidence for a direct negative effect of estradiol at the level of the pituitary gland in sheep. Biol. Reprod. 43, 554-558.

Nett, T.M., Crowder-Sousa, M.E., Herring, R.D. \& Hamernik, D.L. (1990b) Effect of GnRH, progesterone, and oestradiol on pituitary content of mRNAs for subunits of gonadotropins in sheep. In Glycoprotein Hormones, pp. 151-159. Eds W. Chin \& I. Boime. Plenum, New York.

Nilson, J.H., Nejedlik, M.T., Virgin, J.B., Crowder, M.E. \& Nett, T.M. (1983) Expression of $\alpha$-subunit and luteinizing hormone $\beta$ genes in the ovine anterior pituitary. Oestradiol suppresses accumulation of mRNAs for both $\alpha$-subunit and luteinizing hormone B. J. Biol. Chem. 258, 12087-12090.

Niswender, G.D., Reichert, L.E., Midgley Jr., A.R. \& Nalbandov, A.V. (1969) Radioimmunoassay for bovine and ovine luteinizing hormone. Endocrinology 84, $1166-1173$.

Phillips, C.L., Lin, L.W., Wu, J.C., Guzman, K., Milsted, A. \& Miller, W. (1988) 17ß-Oestradiol and progesterone inhibit transcription of the genes encoding the subunits of ovine follicle-stimulating hormone. $\mathrm{Mol}$. Endocr. 2, 641-649.

Shupnik, M.A., Soheyla, D.G. \& Chin, W.W. (1988) Estrogen suppresses rat gonadotropin gene transcription in vivo. Endocrinology 122, 1842-1846.

Shupnik, M.A., Weinmann, C.M., Notides, A.C. \& Chin, W.W. (1989) An upstream region of the rat luteinizing hormone $\beta$ gene binds estrogen receptor and confers estrogen responsiveness. J. Biol. Chem. 264, $80-86$.
Stabenfeldt, G.H., Drost, M. \& Franti, C.E. (1972) Peripheral plasma progesterone levels in the ewe during pregnancy and parturition. Endocrinology $\mathbf{9 0}$, $144-150$.

Steel, R.G.D. \& Torrie, J.H. (1980) Principles and Procedures of Statistics; A Biomedical Approach. McGraw-Hill, New York.

Tamanini, C., Crowder, M.E. \& Nett, T.M. (1986) Effect of oestradiol and progesterone on pulsatile secretion of luteinizing hormone in ovariectomized ewes. Acta Endocr., Copnh. 111, 172-178.

Tamanini, C., Crowder, M.E. \& Nett, T.M. (1988) Progesterone does not inhibit the increase in pituitary content of luteinizing hormone after removal of oestradiol in the ewe. Acta endocr., Copnh. 118, 193-198.

Virgin, J.B., Silver, B.J., Thomason, A.R. \& Nilson, J.H. (1985) The gene for the $\beta$ subunit of bovine luteinizing hormone encodes a gonadotropin mRNA with an unusually short 5 -untranslated region. J. Biol. Chem. 260, 7072-7077.

Wise, M.E., Nilson, J.H., Nejedlik, M.T. \& Nett, T.M. (1985) Measurement of messenger RNA for luteinizing hormone $\beta$-subunit and $\alpha$-subunit during gestation and the postpartum period in the ewes. Biol. Reprod. 33, 1009-1015.

Wise, M.E., Sawyer, H.R. \& Nett, T.M. (1986) Functional changes in luteinizing hormone-secreting cells from pre- and postpartum ewes. Am. J. Physiol. 250, E282-E287.

Woychik, R.P., Camper, S.A., Lyons, R.H., Horowitz, S., Goodwin, E.C. \& Rottman, P.M. (1982) Cloning and nucleotide sequencing of the bovine growth hormone gene. Nucleic Acids Res. 10, 7197-7211.

Received 31 August 1990 